\title{
Impact of excipients in the chronic toxicity of fluoxetine on the alga Chlorella vulgaris
}

\author{
Aurora Silva, Lúcia H. M. L. M. Santos, Cristina Delerue-Matos, Sónia A. Figueiredo
}

\begin{abstract}
Fluoxetine is a selective serotonin reuptake inhibitor (SSRI) widely used in the treatment of major depression. It has been detected in surface and wastewaters, being able to negatively affect aquatic organisms. Most of the ecotoxicity studies focused only in pharmaceuticals, though excipients can also pose a risk to non-target organisms. In this work the ecotoxicity of five medicines (three generic formulations and two brand labels) containing the same active substance (fluoxetine hydrochloride) was tested on the alga Chlorella vulgaris, in order to evaluate if excipients can influence their ecotoxicity. Effective con-centrations that cause $50 \%$ of inhibition $\left(\mathrm{EC}_{50}\right)$ ranging from 0.25 to $15 \mathrm{mg} \mathrm{L}^{-1}$ were obtained in the growth inhibition test performed for the different medicines. The corresponding values for fluoxetine concentration are 10 times lower. Higher $\mathrm{EC}_{50}$ values had been published for the same alga considering only the toxicity of fluoxetine. Therefore, this increase in toxicity may be attributed to the presence of excipients. Thus more studies on ecotoxicological effects of excipients are required in order to assess the environmental risk they may pose to aquatic organisms.
\end{abstract}

Keywords: Antidepressant, Chlorella vulgaris, ecotoxicity, excipients, fluoxetine

\section{Introduction}

Over the last decade, the consumption of antidepressants has considerably been growing in Europe [1] and Iceland, Denmark and Portugal head the ranking of the European countries with the highest levels of consumption.[2]

Selective serotonin reuptake inhibitors (SSRIs) are amongst the most widely used antidepressants, fluoxetine being one of the most prescribed.[3] It stands out in the treatment of major depression, anxiety disorders and obsessivecompulsive disorders [4] and acts by inhibiting the reuptake of the neurotransmitter serotonin from the synaptic cleavage, enhancing serotonergic neurotransmission.[4]

Fluoxetine has been detected in surface waters [5-9] and wastewaters [10-13] within the $\mathrm{n} \mathrm{L}^{-1}$ range. In Canada, it was detected in surface waters adjacent to discharges of wastewater treatment plants (WWTPs) effluents reaching maximum concentrations of $46 \mathrm{ng} \mathrm{L}^{-1}$.[14]

Discharge of WWTPs was identified as one of the most important sources of entrance of pharmaceuticals into the environment. However, direct disposal of pharmaceuticals into the sink/toilet or via waste collection can also be pointed out as sources of environmental contamination by pharmaceuticals.[15,16] Therefore, besides the ecotoxicological risk caused by pharmaceuticals, environmental risk assessment should also be extended to excipients, since they are an import part of the final medicine. However, in literature, environmental risk assessment of excipients is rarely focused.[17,18]
Serotonin is also an important neurotransmitter in hormonal and neuronal mechanisms, participating in regulatory and endocrine functions in lower vertebrates and invertebrates.[15] Thus, the presence of fluoxetine in the environment, even at low concentrations (few $\mathrm{ng} \mathrm{L}^{-1}$ ), can adversely affect aquatic organisms. Christensen et al. [19] studied five SSRIs toxicity towards algae and crustaceans, showing that fluoxetine was the most toxic for the alga Pseudokirchneriella subcapitata with an effective concentration that causes $50 \%$ of inhibition $\left(\mathrm{EC}_{50}\right)$, for a $48 \mathrm{~h}$ period, of $27 \mu \mathrm{g} \mathrm{L}^{-1}$; while Brooks et al. [20] reported a decrease in $P$. subcapitata growth when exposed to $14 \mu \mathrm{g} \mathrm{L}^{-1}$ of fluoxetine. The same authors also described a decrease in Ceriodaphnia dubia fecundity for concentrations of $223 \mu \mathrm{g} \mathrm{L}^{-1}$.[21] Fish species are also affected by the exposure to fluoxetine, which is able to significantly reduce their growth [22] and also affect their reproduction, being reported an increase in developmental abnormalities in fish embryos as well as in the plasmatic concentration of oestradiol in females.[23] On the other hand, the locomotion of the epibenthic crab Carcinus maenas is significantly increased for concentrations of fluoxetine equal or above $120 \mu \mathrm{g} \mathrm{L}^{-1}$.[24]

In the present work, the toxicity of five medicines (three generic and two brand labels) used in the treatment of depression, which are available in the Portuguese market, was tested on the alga Chlorella vulgaris. All the medicines have the same active substance - fluoxetine. Their effect in 
Table 1. Excipients of the studied medicines according to the producers.

\begin{tabular}{|c|c|c|c|c|}
\hline Digassim & Prozac & Fluoxetina Actavis & Fluoxetina Ratiopharm & Fluoxetina Sandoz \\
\hline Cornstarch & Cornstarch & Pre-gelatinized cornstarch & Lactose monohydrate & Microcrystalline cellulose \\
\hline Dimethicone & Dimethicone & Anhydrous colloidal silica & Microcrystalline cellulose & Pre-gelatinized starch \\
\hline Gelatine $^{\mathrm{a}}$ & Patent blue V (E131) ${ }^{\mathrm{a}}$ & Magnesium stearate & Magnesium stearate & Talc \\
\hline $\begin{array}{l}\text { Titanium oxide } \\
(\mathrm{E} 171)^{\mathrm{a}}\end{array}$ & $\begin{array}{l}\text { Yellow iron oxide } \\
(\text { E172) }\end{array}$ & Talc & Anhydrous colloidal silica & Gelatine $^{\mathrm{a}}$ \\
\hline $\begin{array}{l}\text { Indigo carmine } \\
(\mathrm{E} 132)^{\mathrm{a}}\end{array}$ & $\begin{array}{l}\text { Titanium oxide } \\
(\mathrm{E} 171)^{\mathrm{a}}\end{array}$ & Quinoline yellow (E104) ${ }^{\mathrm{a}}$ & Gelatine $^{\mathrm{a}}$ & Yellow iron oxide $(\mathrm{E} 172)^{\mathrm{a}}$ \\
\hline $\begin{array}{l}\text { Red iron oxide } \\
\quad(\text { E172) }\end{array}$ & $\begin{array}{l}\text { Gelatine }^{\mathrm{a}} \\
\text { Shellac }^{\mathrm{a}} \\
\text { Black iron oxide } \\
\quad(\mathrm{E} 172)^{\mathrm{a}}\end{array}$ & 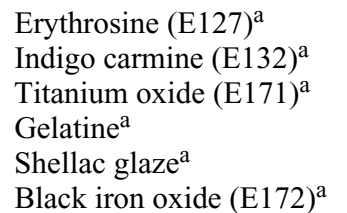 & $\begin{array}{l}\text { Titanium dioxide }(\mathrm{E} 171)^{\mathrm{a}} \\
\text { Yellow iron oxide }(\mathrm{E} 172)^{a} \\
\text { Quinoline yellow }(\mathrm{E} 104)^{\mathrm{a}} \\
\text { Indigo carmine }(\mathrm{E} 132)^{\mathrm{a}}\end{array}$ & $\begin{array}{l}\text { Titanium oxide }(\mathrm{E} 171)^{\mathrm{a}} \\
\text { Shellac }^{\mathrm{a}} \\
\text { Soy lecithin } \\
\text { Antifoam dc150 } \\
\text { Black iron oxide }(\mathrm{E} 172)^{\mathrm{a}}\end{array}$ \\
\hline
\end{tabular}

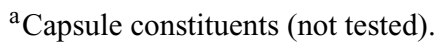

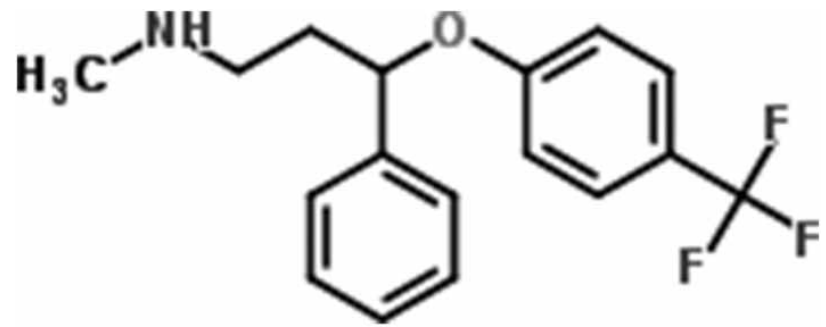

Figure 1. Chemical structure of fluoxetine.

the growth rate of the alga was evaluated over a 72-h period. The aim of the work was to evaluate the chronic toxicity of fluoxetine in this alga as well as to assess the contribution of excipients for the observed toxicity. Algae were chosen as test organisms because any disturbance in their dynamics might affect the higher levels of trophic chain. The unicellular green alga $C$. vulgaris was selected as test organism due to its good sensitivity to toxicants, $[25,26]$ it is easily cultured in laboratory $[27,28]$ and is representative of the algae present in nature, being found in freshwater, saltwater and soil.[29]

\section{Materials and methods \\ Test substances}

Five medicines containing fluoxetine hydrochloride as active substance were studied. Three of them are generic (Fluoxetina Actavis ${ }^{\circledR}$, Fluoxetina Rathiopharm ${ }^{\circledR}$ and Fluoxetina Sandoz ${ }^{\circledR}$ ); and Digassim and Prozac are two brand labels from Vitória and Lilly laboratories, respectively. All the medicines are commercialized as capsules and were obtained in the local market. Each capsule contains $20 \mathrm{mg}$ of fluoxetine hydrochloride, which corresponds to approximately $10 \%$ of the capsule content, and different excipients that are enumerated in Table 1 by decreasing order of weight percentage. Only the capsule content was used in tests. The chemical structure of fluoxetine is presented in Figure 1.

\section{Test organism}

The ecotoxicity tests were carried out with the freshwater unicellular green alga $C$. vulgaris. The test organism was cultured in laboratory under aseptic conditions. A new culture was started weekly by aseptically transferring $1-2 \mathrm{~mL}$ of stock culture to a $50-100 \mathrm{~mL}$ of new culture medium in order to adapt the alga to the test conditions and ensure that the alga is in exponential growth phase when it was used to inoculate the test solutions. The stock cultures were kept at $21 \pm 2{ }^{\circ} \mathrm{C}$, under cool white fluorescent lighting, for four days. Agitation was performed by filtered air bubbling. Each stock culture was examined with an optical microscope (Nikon Alphaphot-2 YS2) to ensure that there were no contaminating microorganisms. The medium for the algal growth inhibition test was prepared in accordance with the OECD Test Guideline 201,[30] using deionized water with conductivity lower than $5 \mu \mathrm{S} \mathrm{cm}^{-1}$ and suitable nutrients. The final $\mathrm{pH}$ of the nutrient medium solution was approximately 8 .

\section{Bioassays}

The tests were carried out based on the OECD 201 Guidelines and the US EPA suggested procedure.[30,31] The algae population was exposed in a static non-renewal system, to series of different concentrations of medicine between 0.25 and $18.5 \mathrm{mg} \mathrm{L}^{-1}$, for $72 \pm 2 \mathrm{~h}$, in order to evaluate its chronic toxicity. The test temperature was $21-24 \pm 2{ }^{\circ} \mathrm{C}$ (maximum variation $=3{ }^{\circ} \mathrm{C}$ ), using continuous illumination ('Cool white' fluorescent lighting, 6000 to $10,000 \mathrm{lux}$ ) and a test solution volume of $100 \mathrm{~mL}$. Three replicates were tested.

The inoculum of the green alga, C. vulgaris, provided a concentration around $10^{6}$ cells $/ \mathrm{mL}$ in each test flask. Initial biomass did not exceed $0.5 \mathrm{mg} \mathrm{L}^{-1}$ as dry weight, allowing exponential growth through the incubation period, without risk of nutrient depletion. Aseptic techniques were used in the algal cultures, handling and extreme 
care were exercised to avoid contamination. A laminar air flow chamber (FASTER, model two-30) and a sterilization chamber (AJC, model Uniclave 88) were used.

A set of four different concentrations and a control were used for each sample tested, except for Fluoxetina Sandoz for which an additional lower concentration was tested. The diluted water was the culture medium, in order to avoid nutrient limitation.

The test flaks position was randomized and changed daily, being agitated twice by hand. The agitation by air bubbling was not used in order to prevent changes in the concentration and $\mathrm{pH} .[30,31]$

The growth of the algae population was measured in terms of changes in cell density, which was evaluated by optical density (Shimadzu UV-2101 PC spectrophotometer) at $440 \mathrm{~nm} .[28,32]$ A linear relationship was verified between cell counts and biomass versus optical density. The optical microscope was used for cell counts. The biomass was determined by filtration over a $0.45 \mu \mathrm{m}$ membrane (GN-6 Metricel Grid, Pall Corporation) followed by drying until constant weight.

The $\mathrm{pH}\left(\right.$ Crison ${ }^{\circledR} \mathrm{CWL} / \mathrm{s} 7$ combined glass electrode connected to a decimilivoltammeter Crison $\AA$, $\mathrm{pH}$ meter, GLP 22) was evaluated in the beginning and at the end of the test, its variation should not exceed 1.5.

The test conditions were validated through the use of a reference toxicant, the potassium dichromate, tested in the same conditions.[31]

\section{Data analysis}

The optical density values obtained at $440 \mathrm{~nm}$ [32] were transformed in cell density (cells/mL) using the linear experimental relation previously determined. The acceptability criterion considered was variability less than $20 \%$ among replicates.

The statistical analysis of results was done as suggested by EPA.[31] The $\mathrm{EC}_{50}$ was calculated using a point estimation technique, the linear interpolation method. Due to the use of a linear interpolation technique to calculate an estimate of the $\mathrm{EC}_{50}$, standard statistical methods for calculating confidence intervals are not applicable.

\section{Results and discussion}

The chronic toxicity of five medicines (three generic and two brand labels) with the same active substance (fluoxetine) was tested on the alga $C$. vulgaris. Considering that medicines were tested as a whole (pharmaceutical plus excipients) and subjected to a very rigorous quality control (concentrations and stability) by pharmaceutical industry, it was assumed that the real concentrations of fluoxetine are the nominal ones. According to literature $[30,31]$ it was considered that there was no significant change in the nominal concentration during the test period (less than 20\%). Moreover fluoxetine has low volatility
Table 2. Toxicity of the five studied medicines containing fluoxetine to Chlorella vulgaris.

\begin{tabular}{lc}
\hline Medicine & $72 \mathrm{~h} \mathrm{EC}_{50}\left(\mathrm{mg} \mathrm{L}^{-1}\right)$ \\
\hline Fluoxetina Actavis & 0.57 \\
Fluoxetina Ratiopharm & 15 \\
Fluoxetina Sandoz & 0.25 \\
Digassim & 3.8 \\
Prozac & 8.1 \\
\hline
\end{tabular}

and biodegradability, being described as one of the most persistent pharmaceuticals in the environment.[33]

The obtained average inhibition rates, and also the maximum and minimum values, are presented in Figure 2. It was noticed that there was an increasing growth inhibition of algae to increasing concentrations of the tested medicine.

$\mathrm{EC}_{50}$ ranging from 0.25 to $15 \mathrm{mg} \mathrm{L}^{-1}$ were obtained in the growth inhibition test performed on $C$. vulgaris for the different medicines (Table 2 ). The corresponding values for fluoxetine content are 10 times lower. Nevertheless, a higher value $\left(\mathrm{EC}_{50}=4.3 \mathrm{mg} \mathrm{L}^{-1}\right)$ was previously published for C. vulgaris, when exposed to fluoxetine for a period of $96 \mathrm{~h},[34]$ albeit the incubation time used was lower (72 h).

Although similar $\mathrm{EC}_{50}$ values were reported in literature for the algae Scenedesmus acutus and $S$. quadricauda, with EC $_{50}$ of 91 and $213 \mu \mathrm{g} \mathrm{L}^{-1}$, respectively,[34] and also for $P$. subcapitata $\left(\mathrm{EC}_{50}\right.$ ranging from 24 to $\left.90 \mu \mathrm{g} \mathrm{L}^{-1}\right)$. [3,19,20, 34] The latter also showed smaller cells with deformities for 13.6 $\mu \mathrm{g} \mathrm{L}^{-1}$ of fluoxetine.[20] On the other hand, this SSRI did not show any effect on the efficiency of photosynthesis of $P$. subcapitata. [3]

In the present study the medicines were tested as a whole (active substance plus excipients), since the quantitative composition of the medicine is not of public domain and excipients represent $90 \%$ of their total weight. They share the same active substance (fluoxetine), so differences in their toxicity might be attributed to the excipients attending that: all test conditions were the same, being controlled and kept constant; experiments were made in triplicate, the results being reproducible among replicates; the only parameter that changed was the supplier of the medicine, which implies different composition in terms of excipients and their quantities.

As it was mentioned, $\mathrm{EC}_{50}$ values are lower than data for fluoxetine toxicity in C. vulgaris, which could be attributed to the presence of excipients. In accordance with literature, most of the excipients present in the studied medicines (Table 1), namely starch, cellulose and lactose, are considered environmentally safe.[17] The lowest $\mathrm{EC}_{50}$ values were obtained with two generic formulations (Fluoxetina Sandoz and Fluoxetina Actavis). This could be due to the presence of talc in their formulations (Table 1), which might have caused some turbidity in the test solution decreasing the penetration of light and, consequently, the growth of the alga. 

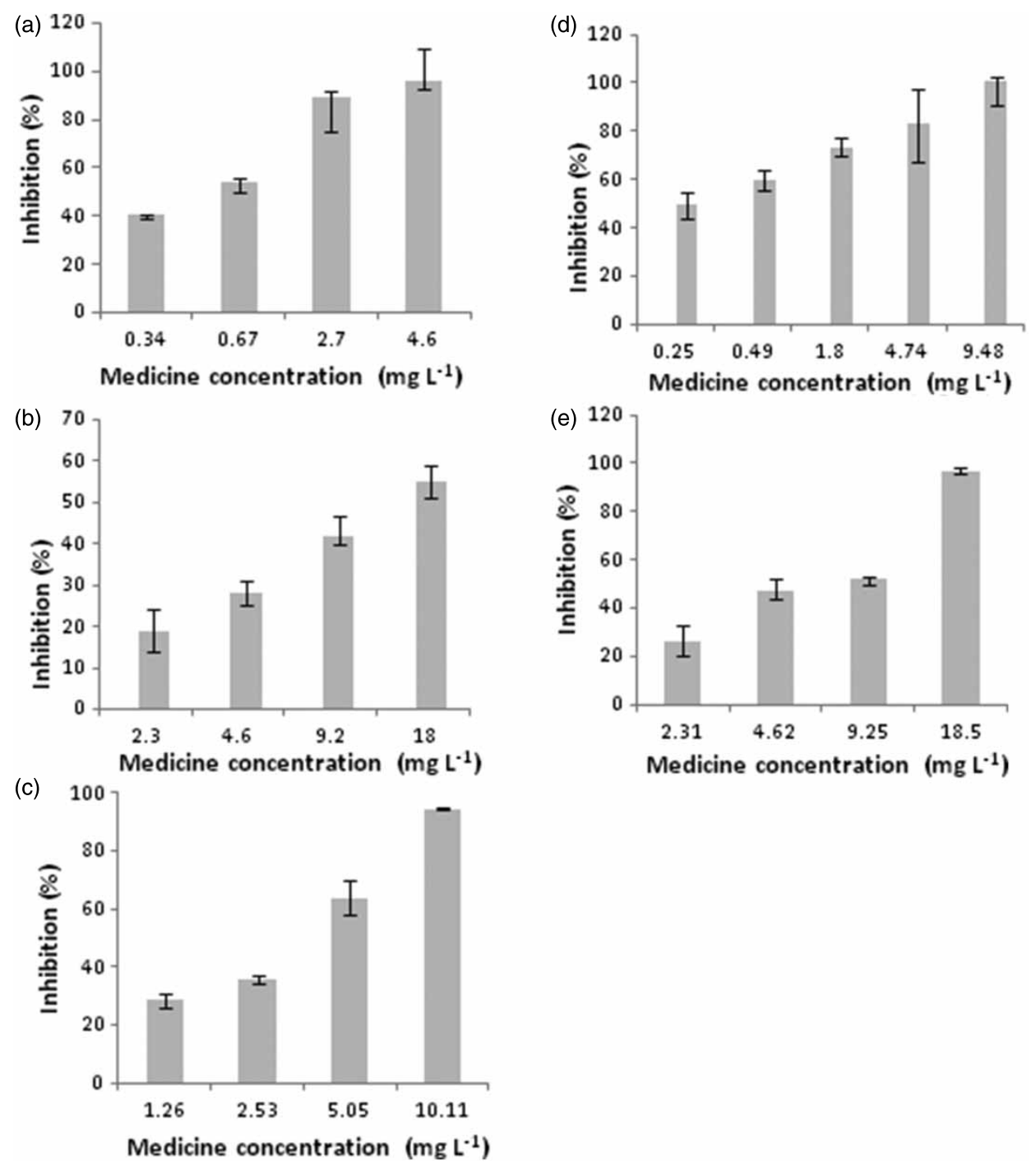

Figure 2. Inhibition rates for: (a) Fluoxetina Actavis; (b) Fluoxetina Rathiopharm; (c) Fluoxetina Sandoz; (d) Digassim; (e) Prozac.

Fluoxetine has been detected in surface waters at concentrations of few $\mathrm{ng} \mathrm{L}^{-1}$. For example, $66.1 \mathrm{ng} \mathrm{L}^{-1}$ were detected in the Henares-Jarama-Tajo river system (Spain),[9] in USA surface waters levels can go upto $43.2 \mathrm{ng} \mathrm{L}^{-1}$, [7] while in St Lawrence river (Canada) concentrations ranging from 0.42 to $1.3 \mathrm{ng} \mathrm{L}^{-1}$. [5] Attending to the $\mathrm{EC}_{50}$ values obtained in the present study (Table 2), environmental concentrations of fluoxetine may not pose a risk for algae. However, it was proved that different SSRIs can have additive effects, $[3,19]$ therefore as pharmaceuticals contaminate the environment as a mixture and not as single compounds, should be taken into account that fluoxetine might have toxicity for non-target organisms even at lower concentrations. On the other hand, the chronic exposure of fish to low levels of fluoxetine may cause negative effects in reproduction or behavioural functions.[20] For instance, a decrease in swimming velocity was observed when the Arabian killifish was exposed to concentrations of fluoxetine as lower as $0.03 \mu \mathrm{g} \mathrm{L}^{-1}$,[35] while a delay in the development of external sexual morphology in both male and female western mosquitofish was reported for the levels of $71 \mu \mathrm{g} \mathrm{L}^{-1}$.[36]

In fact, fluoxetine was included in a shortlist of 10 pharmaceuticals potentially dangerous for aquatic organisms due to environmental exposure (by WWTP effluents) that should be further monitored.[37]

\section{Conclusions}

The evaluation of chronic toxicity of five medicines (three generic and two brand labels) with the same active substance (fluoxetine) to the alga $C$. vulgaris was performed on a $72 \mathrm{~h}$ growth inhibition test. $\mathrm{EC}_{50}$ ranging from 0.25 to $15 \mathrm{mg} \mathrm{L}^{-1}$ were obtained for the studied medicines, corresponding to concentrations 10 times lower than that of fluoxetine. Higher $\mathrm{EC}_{50}$ values were reported in literature for the same alga, taking into account only the toxicity of fluoxetine. Therefore, the observed increase in 
toxicity may be attributed to the presence of excipients. However, nowadays there is a scarce knowledge in ecotoxicity of excipients present in pharmaceutical products. Although they are present in small amounts, environmental risk assessment should consider the whole medicine (active substance(s) plus excipients). Therefore more studies on ecotoxicological effects of excipients are required in order to assess the environmental risk they may pose to aquatic organisms, since they show a more realistic impact of medicines than testing only their individual constituents.

\section{Acknowledgements}

This work has been financially supported by the 'Fundação para a Ciência e a Tecnologia (FCT)' through projects PEst-C/EQB/ LA0006/2011, PTDC/ECM/103141/2008 and PTDC/AAGTEC/2692/2012.

\section{References}

[1] Gusmão R, Quintão S, McDaid D, Arensman E, Van Audenhove C, Coffey C, Värnik A, Värnik P, Coyne J, Hegerl U. Antidepressant utilization and suicide in Europe: an ecological multi-national study. Plos One. 2013;8:e66455. Available from: doi:10.1371/journal.pone.0066455

[2] OECD. Health at a glance: Europe 2012. OECD Publishing; 2012. Available from: http://dx.doi.org/10.1787/ 9789264183896-en

[3] Neuwoehner J, Fenner K, Escher BI. Physiological modes of action of Fluoxetine and its human metabolites in algae. Environ Sci Technol. 2009;43:6830-6837.

[4] Simpson K, Noble S. Fluoxetine: a review of its use in women's health. CNS Drugs. 2000;14:301-328.

[5] Lajeunesse A, Gagnon C, Sauve S. Determination of basic antidepressants and their n-desmethyl metabolites in raw sewage and wastewater using solid-phase extraction and liquid chromatography - Tandem mass spectrometry. Anal Chem. 2008;80:5325-5333.

[6] Metcalfe CD, Chu S, Judt C, Li H, Oakes KD, Servos MR, Andrews DM. Antidepressants and their metabolites in municipal wastewater, and downstream exposure in an urban watershed. Environ Toxicol Chem. 2010;29:79-89.

[7] Schultz MM, Furlong ET, Kolpin DW, Werner SL, Schoenfuss HL, Barber LB, Blazer VS, Norris DO, Vajda AM. Antidepressant pharmaceuticals in two US effluent-impacted streams: occurrence and fate in water and sediment, and selective uptake in fish neural tissue. Environ Sci Technol. 2010;44:1918-1925.

[8] Bringolf RB, Heltsley RM, Newton TJ, Eads CB, Fraley SJ, Shea D, Cope WG. Environmental occurrence and reproductive effects of the pharmaceutical fluoxetine in native freshwater mussels. Environ Toxicol Chem. 2010;29: 1311-1318.

[9] Fernández C, González-Doncel M, Pro J, Carbonell G, Tarazona JV. Occurrence of pharmaceutically active compounds in surface waters of the Henares-Jarama-Tajo river system (Madrid, Spain) and a potential risk characterization. Sci Total Environ. 2010;408:543-551.

[10] van Nuijs ALN, Tarcomnicu I, Simons W, Bervoets L, Blust R, Jorens PG, Neels H, Covaci A. Optimization and validation of a hydrophilic interaction liquid chromatography-tandem mass spectrometry method for the determination of 13 top-prescribed pharmaceuticals in influent wastewater. Anal Bioanal Chem. 2010;398:2211-2222.
[11] Vasskog T, Anderssen T, Pedersen-Bjergaard S, Kallenborn $\mathrm{R}$, Jensen E. Occurrence of selective serotonin reuptake inhibitors in sewage and receiving waters at Spitsbergen and in Norway. J Chromatogr A. 2008;1185:194-205.

[12] Yu K, Li B, Zhang T. Direct rapid analysis of multiple PPCPs in municipal wastewater using ultrahigh performance liquid chromatography-tandem mass spectrometry without SPE pre-concentration. Anal Chim Acta. 2012;738: 59-68.

[13] Garcia N, Moreno J, Cartmell E, Rodriguez-Roda I, Judd S. The application of microfiltration-reverse osmosis/nanofiltration to trace organics removal for municipal wastewater reuse. Environ Technol. 2013;34:3183-3189.

[14] Metcalfe CD, Miao XS, Koenig BG, Struger J. Distribution of acidic and neutral drugs in surface waters near sewage treatment plants in the lower Great Lakes, Canada. Environ Toxicol Chem. 2003;22:2881-2889.

[15] Santos LHMLM, Araujo AN, Fachini A, Pena A, DelerueMatos C, Montenegro MCBSM. Ecotoxicological aspects related to the presence of pharmaceuticals in the aquatic environment. J Hazard Mat. 2010;175:45-95.

[16] Jones OAH, Voulvoulis N, Lester JN. Human pharmaceuticals in the aquatic environment a review. Environ Technol. 2001;22:1383-1394.

[17] Carlsson C, Johansson A-K, Alvan G, Bergman K, Kühler T. Are pharmaceuticals potent environmental pollutants?: Part II: environmental risk assessments of selected pharmaceutical excipients. Sci Total Environ. 2006;364:88-95.

[18] Straub JO. Environmental risk assessment for new human pharmaceuticals in the European Union according to the draft guideline/discussion paper of January 2001. Toxicol Lett. 2002; 131:137-143.

[19] Christensen AM, Faaborg-Andersen S, Ingerslev F, Baun A. Mixture and single-substance toxicity of selective serotonin reuptake inhibitors toward algae and crustaceans. Environ Toxicol Chem. 2007;26:85-91.

[20] Brooks BW, Foran CM, Richards SM, Weston J, Turner PK, Stanley JK, Solomon KR, Slattery M, La Point TW. Aquatic ecotoxicology of fluoxetine. Toxicol Lett. 2003;142: 169-183.

[21] Brooks BW, Turner PK, Stanley JK, Weston JJ, Glidewell EA, Foran CM, Slattery M, La Point TW, Huggett DB. Waterborne and sediment toxicity of fluoxetine to select organisms. Chemosphere. 2003;52:135-142.

[22] Stanley JK, Ramirez AJ, Chambliss CK, Brooks BW. Enantiospecific sublethal effects of the antidepressant fluoxetine to a model aquatic vertebrate and invertebrate. Chemosphere. 2007;69:9-16.

[23] Foran CM, Weston J, Slattery M, Brooks BW, Huggett DB. Reproductive assessment of Japanese Medaka (Oryzias latipes) following a four-week Fluoxetine (SSRI) exposure. Arch Environ Contam Toxicol. 2004;46:511-517.

[24] Mesquita SR, Guilhermino L, Guimarães L. Biochemical and locomotor responses of Carcinus maenas exposed to the serotonin reuptake inhibitor fluoxetine. Chemosphere. 2011;85:967-976.

[25] Ma J, Lin F, Zhang R, Yu W, Lu N. Differential sensitivity of two green algae, Scenedesmus quadricauda and Chlorella vulgaris, to 14 pesticide adjuvants. Ecotoxicol Environ Saf. 2004;58:61-67.

[26] Murray D, Jefferson B, Jarvis P, Parsons SA. Inhibition of three algae species using chemicals released from barley straw. Environ Technol. 2010;31:455-466.

[27] Gomes AI, Pires JCM, Figueiredo SA, Boaventura RAR. Multiple linear and principal component regressions for modelling ecotoxicity bioassay response. Environ Technol. 2014;35:945-955. 
[28] Silva A, Figueiredo SA, Sales MG, Delerue-Matos C. Ecotoxicity tests using the green algae Chlorella vulgaris A useful tool in hazardous effluents management. J Hazard Mat. 2009;167:179-185.

[29] Pelczar M, Chan E, Krieg N. Microbiology: concepts and applications. 1st ed. New York: McGraw-Hill; 1993, p. 288.

[30] OECD. OECD Guidelines for the testing of chemicals freshwater alga and cyanobacteria, growth inhibition test; 2006.

[31] USEPA. Short-term methods for estimating the chronic toxicity of effluents and receiving waters to fresh water organisms (Fourth Edition) EPA-821-R-02-013. Washington D.C. US Environmental Protection Agency; 2002.

[32] Carvalho F, Guilhermino L, Ribeiro R, Gonçalves F, Soares AMVM. METIER (modular ecotoxicity tests incorporating ecological relevance). II. Ecotoxicity of poorly water-soluble compounds: Concentration versus dose. Arch Environ Contam Toxicol. 1995;29:431-434.

[33] Redshaw CH, Cooke MP, Talbot HM, McGrath S, Rowland SJ. Low biodegradability of fluoxetine $\mathrm{HCl}$, diazepam and their human metabolites in sewage sludge-amended soil. J Soils Sediments. 2008;8:217-230.

[34] Johnson DJ, Sanderson H, Brain RA, Wilson CJ, Solomon KR. Toxicity and hazard of selective serotonin reuptake inhibitor antidepressants fluoxetine, fluvoxamine, and sertraline to algae. Ecotoxicol Environ Saf. 2007;67: $128-139$

[35] Barry MJ. Effects of fluoxetine on the swimming and behavioural responses of the Arabian killifish. Ecotoxicology. 2013;22:425-432.

[36] Henry TB, Black MC. Acute and chronic toxicity of fluoxetine (selective serotonin reuptake inhibitor) in western mosquitofish. Arch Environ Contam Toxicol. 2008;54: 325-330.

[37] Santos LHMLM, Gros M, Rodriguez-Mozaz S, DelerueMatos C, Pena A, Barceló D, Montenegro MCBSM. Contribution of hospital effluents to the load of pharmaceuticals in urban wastewaters: Identification of ecologically relevant pharmaceuticals. Sci Total Environ. 2013;461-462: 302-316. 